\title{
Bacteriocins from Lactic Acid Bacteria: Purification, Properties and use as Biopreservatives
}

\author{
José Luis Parada, Carolina Ricoy Caron, Adriane Bianchi P. Medeiros and Carlos Ricardo \\ Soccol $^{*}$ \\ Unidade de Biotecnologia Industrial; Divisão de Bioprocessos e Biotecnologia; Setor de Tecnologia; Universidade \\ Federal do Paraná; C. P. 19011; 81531-990; soccol@ufpr.br; Curitiba - PR - Brasil
}

\begin{abstract}
Biopreservation systems in foods are of increasing interest for industry and consumers. Bacteriocinogenic lactic acid bacteria and/or their isolated bacteriocins are considered safe additives (GRAS), useful to control the frequent development of pathogens and spoiling microorganisms in foods and feed. The spreading of bacterial antibiotic resistance and the demand for products with fewer chemicals create the necessity of exploring new alternatives, in order to reduce the abusive use of therapeutic antibiotics. In this context, bacteriocins are indicated to prevent the growth of undesirable bacteria in a food-grade and more natural way, which is convenient for health and accepted by the community. According to their properties, structure, molecular weight $(M W)$, and antimicrobial spectrum, bacteriocins are classified in three different groups: lantibiotics and nonlantibiotics of low MW, and those of higher MW. Several strategies for isolation and purification of bacteriocins from complex cultivation broths to final products were described. Biotechnological procedures including saltingout, solvent extraction, ultrafiltration, adsorption-desortion, ion-exchange, and size exclusion chromatography are among the most usual methods. Peptide structure-function studies of bacteriocins and bacterial genetic advances will help to understand the molecular basis of their specificity and mode of action. Nisin is a good example of commercial success, and a good perspective is open to continue the study and development of new bacteriocins and their biotechnological applications. These substances in appropriate concentrations may be used in veterinary medicine and as animal growth promoter instead usual antibiotics, as well as an additional hurdle factor for increasing the shelf life of minimal processed foods.
\end{abstract}

Key words: Lactic acid bacteria, bacteriocins, purification, food preservation

\section{INTRODUCTION}

One of the concerns in food industry is the contamination by pathogens, which are frequent cause of food borne diseases. Over the past decade, recurrent outbreaks of diarrhea, combined with the natural resistance of the causative agents, contributed to its status as hazard.

The problem of selection of resistant bacteria to antibiotics (Parada, 1980; Chopra et al, 1997; Rao,
1998; Kapil, 2005) and the increasing demand for safe foods, with less chemical additives, has increased the interest in replacing these compounds by natural products, which do not injure the host or the environment. Biotechnology in the food-processing sector targets the selection, production and improvement of useful microorganisms and their products, as well as their technical application in food quality.

\footnotetext{
* Author for correspondence
} 
The use of non-pathogenic microorganisms and/or their metabolites to improve microbiological safety and extend the shelf life of foods is defined as biopreservation (De Martinis et al, 2001).

Antagonistic properties of lactic acid bacteria (LAB) allied to their safe history of use in traditional food fermented products make them very attractive to be used as biopreservatives (Parada, 1984; Caplice and Fitzgerald, 1999).

Antibiotics are at present restricted for use in foods and feeds, and bacteriocins are an interesting group of biomolecules with antimicrobial properties that may represent a good alternative (Jack et al, 1995).

The increasing interest in these compounds has stimulated the isolation of LAB producers and the characterization of many novel peptides (Deraz et al, 2005).

The successful development of nisin from an initial biological observation through regulatory approval for commercial applications, is a model that has stimulated new contributions in the field of bacteriocin research (Deegan et al, 2006).

\section{Lactic Acid Bacteria}

Lactic acid bacteria (LAB) are characterized as Gram-positive cocci or rods, non-aerobic but aerotolerant, able to ferment carbohydrates for energy and lactic acid production. The metabolic pathway from glucose may be homofermentative or heterofermentative. In the first case two molecules of lactate are generated (as in Streptococcus and Lactococcus), and in the second, lactate, ethanol and carbon dioxide are produced, as in Leuconostoc and some lactobacilli. Lactic acid bacteria are also able to produce small organic substances that contribute with aroma and give specific organoleptic attributes to the products (Caplice and Fitzgerald, 1999).

These microorganisms are found in milk, meat and fermented products, as well as in fermented vegetables and beverages inhibiting the growth of pathogenic and deteriorating microorganisms, maintaining the nutritive quality and improving the shelf life of foods. They have also been used as flavor and texture producers.

Lactic acid bacteria include various major genera: Lactobacillus, Lactococcus, Carnobacterium, Enterococcus, Lactosphaera, Leuconostoc, Melissococcus, Oenococcus, Pediococcus, Streptococcus, Tetragenococcus, Vagococcus and Weissella. Other genera are: Aerococcus,
Microbacterium, Propionibacterium and Bifidobacterium (Carr et al, 2002).

Lactobacillus acidophilus, L. plantarum, L. casei, $L$. casei rhamnosus, $L$. delbrueckii bulgaricus, $L$. fermentum, L. reuteri, Lactococcus lactis lactis, Lactococcus lactis cremoris, Bifidobacterium bifidum, B. infantis, B. adolecentis, B. longum, B. breve, Enterococcus faecalis, Enterococcus faecium, are some of the most common species (Garrity, 1984; Dellaglio et al, 1994), and some strains are recognized as probiotics (Fuller, 1989; Parada et al, 2003).

Sugar fermentation followed by a reduction in $\mathrm{pH}$ due to the production of lactic and other organic acids is an important factor for the inhibition of growth of undesired microorganisms.

The low $\mathrm{pH}$ makes organic acids lipossoluble, allowing them to break through the cell membrane and reach the cytoplasm of pathogens (Haller et al, 2001).

The competition for essential nutrients, accumulation of D-amino-acids and diminution of the oxirredutive potential also contribute to their inhibitory effect.

LAB are usually known as safe (GRAS), and have an important role in the preservation of foods and fermented products. They can be used as natural competitive microbiota or as specific starter cultures under controlled conditions (Cintas et al, 2001). Some of these bacteria produce antagonistic substances, called bacteriocins, which in small amounts are very active against pathogens (Klaenhammer et al, 1994; Moreno et al, 2006).

\section{Bacteriocins}

In recent years bacterial antibiotic resistance has been considered a problem due to the extensive use of classical antibiotics in treatment of human and animal diseases (Roy, 1997; Lipsitch et al, 2000; Yoneyama and Katsumata, 2006). As a consequence, multiple resistant strains appeared and spread causing difficulties and the restricted use of antibiotics as growth promoters. So, the continue development of new classes of antimicrobial agents has become of increasing importance for medicine (Kumar and Schweiser, 2005; Fisher et al, 2005).

In order to control their abusive use in food and feed products, one plausible alternative is the application of some bacterial peptides as antimicrobial substances in place of antibiotics of human application. Among them, bacteriocins produced by lactic acid bacteria have attracted 
increasing attention, since they are active in a nanomolar range and have no toxicity.

Bacteriocins are proteins or complexed proteins biologically active with antimicrobial action against other bacteria, principally closely related species. They are produced by bacteria and are normally not termed antibiotics in order to avoid confusion and concern with therapeutic antibiotics, which can potentially illicit allergic reactions in humans and other medical problems (Deraz et al, 2005).

Bacteriocins differ from most therapeutic antibiotics in being proteinaceous agents that are rapidly digested by proteases in the human digestive tract. They are ribosomally synthesized peptides, and this fact creates the possibility of improving their characteristics to enhance their activitiy and spectra of action (Saavedra et al, 2004).

Antibiotics are generally considered to be secondary metabolites that are inhibitory substances in small concentration, excluding the inhibition caused by metabolic by-products like ammonia, organic acids, and hydrogen peroxide.

It is likely that most if not all bacteria are capable of producing a heterogeneous array of molecules in the course of their growth in vitro (and presumably also in their natural habitats) that may be inhibitory either to themselves or to other bacteria (Jack et al, 1995).

Bacteriocin production could be considered as an advantage for food and feed producers since, in sufficient amounts, these peptides can kill or inhibit pathogenic bacteria that compete for the same ecological niche or nutrient pool. This role is supported by the fact that many bacteriocins have a narrow host range, and is likely to be most effective against related bacteria with nutritive demands for the same scarce resources (Deegan et al, 2006).

\section{Range of activity}

Considering the antimicrobial spectrum, producing species, molecular weight, stability, physicalchemical properties and mode of action of bacteriocins, they form a heterogeneous group. There is the classic type, which has a spectrum of activity only against homologous species, and a second type, less common, which shows action against a wide range of Gram-positive microorganisms. One example of this second type is nisin, which is produced by certain strains of Lactococcus lactis subsp. lactis (De Vuyst, 1994;
Rodriguez, 1996; Moreno et al, 2000). Other is pediocin, produced by Pedicoccus pentosaceus (Moreno et al, 2006).

Nisin, produced by L. lactis subsp. lactis, is active against Gram-negative bacteria, but only when used at high concentrations or when the target cells have been pre-treated with EDTA (Stevens et al, 1991).

Bacteriocins are not frequently active against Gram-negative bacteria. The outer membrane of this class of bacteria acts as a permeability barrier for the cell. It is responsible for preventing molecules such as antibiotics, detergents and dyes from reaching the cytoplasmic membrane (Stevens et al, 1991). However, some studies have already reported bacteriocin activity against this group of bacteria. Examples are plantaricin 35d, produced by Lactobacillus plantarum and active against Aeromonas hydrophila (Messi et al, 2001); bacteriocin ST151BR, produced by Lactobacillus pentosus ST151BR (Torodov and Dicks, 2004) and a bacteriocin produced by Lactobacillus paracasei subsp. paracasei active against Escherichia coli (Caridi, 2002); thermophylin, produced by Streptococcus thermophilus active against E. coli, Yersinia pseudotuberculosis and Yersinia enterocolitica among the Gram-negative species and against several Bacillus species, Listeria monocytogenes and Salmonella typhimurium among the Gram-positives (Ivanova et al, 1998). Bacteriocins ST28MS and ST26MS, produced by Lactobacillus plantarum isolated from molasses (Torodov and Dicks, 2005) inhibited the growth of Escherichia coli and Acinetobacter baumanii along with some Grampositive bacteria. Lade et al (2006) have isolated two Lactobacillus species ( $L$. plantarum and $L$. lactis) from vegetable waste that produced a bacteriocin which inhibitted the growth of E. coli.

\section{Classification of Bacteriocins}

There is a wide number of bacteriocins produced by different LAB (table 1), and they can be classified according to their biochemical and genetic characteristics (Klaenhammer et al, 1994; González-Martínez et al, 2003).

Class I. - Lantibiotics: small $(<5 \mathrm{kDa})$ heat-stable peptides acting on membrane structures; they are extensively modified after translation, resulting in the formation of characteristic thioether aminoacids lanthionine and methyllanthionine. These arise via a two-step process, originated from posttransdutional modifications: firstly, gene-encoded 
serine and threonine are subjected to enzymatic dehydration to give rise to dehydroalanine and dehydrobutyrine, respectively (Sahl and Bierbaum, 1998). A very well known example of this group is nisin (Broadbent et al, 1989).

The lantibiotic bacteriocins were initially divided into two subclasses based on structural similarities. Subclass Ia included relatively elongated, flexible and positively charged peptides; they generally act by forming pores in the cytoplasmatic membranes of sensitive target species. The prototypic lantibiotic nisin is a member of this group.

Subclass $I b$ peptides are characteristically globular, more rigid in structure and are either negatively charged or have no net charge. They exert their action by interfering with essential enzymatic reactions of sensitive bacteria (Deegan et al, 2006).

Class II. - Non-Lantibiotics: bacteriocins of variable molecular weight, but usually small $(<10$ $\mathrm{kDa}$ ), heat-stable, containing regular amino-acids. This group was divided into three subgroups:

Class IIa: peptides active against Listeria, the characteristic representants are pediocin PA-1 (Venema et al, 1997) and sakacin P.

Class IIb: formed by a complex of two distinct peptides. These peptides have little or no activity and it appears to be no sequence similarities between complementary peptides. In this group are lactococcin $\mathrm{G}$ and plantaricins $\mathrm{EF}$ e JK.

Class IIc: Small peptides, heat-stable, which are transported by leader-peptides. In this subclass are found only the bacteriocins divergicin $\mathrm{A}$ and acidocin $\mathrm{B}$.

Class III. - Big peptides, with molecular weight over $30 \mathrm{kDa}$. In this class are helveticins J (Joerger and Klaenhammer, 1986) and V (Vaugham et al, 1992), acidofilicin A and lactacins A and B.

Most of the low molecular weight bacteriocins are highly cationic at $\mathrm{pH} \mathrm{7.0,} \mathrm{and} \mathrm{this} \mathrm{seems} \mathrm{to} \mathrm{be} \mathrm{a}$ unifying feature of both the lantibiotics and nonlantibiotics (Cintas et al, 2001).

Lantibiotics are the most studied and explored industrially. Nisin, a lantibiotic usually produced by Lactococcus lactis subsp. lactis is used as an additive in foods. All of the variants of nisin are active against Gram-positive bacteria, like Listeria $\mathrm{sp}$, Micrococcus sp and also on sporulating bacteria, like Bacillus sp and Clostridium $\mathrm{sp}$ (González-Martínez et al, 2003).
Nisin

Nisin is a peptide formed by 34 amino-acids (Fig. 1), with a small molecular weight, below $5 \mathrm{kDa}$ (Gross and Morell, 1971). Its synthesis is complex, involving processes of transcription, transduction, post-transdutional modifications, secretion, processing and signs of transduction (Guder et al, 2000). There are two variants of this bacteriocin: nisin $\mathrm{A}$ and $\mathrm{Z}$, which differ from each other only by the amino-acid 27. Histidine in nisin $A$ is replaced by asparagin in nisin $\mathrm{Z}$. This bacteriocin is used predominantly in canned foods and dairy products and is especially effective when utilized in the production of processed cheese and cheese spreads acting against heat-resistant spore forming organisms such as Bacillus and Clostridium (Deegan et al, 2006). It is also effective against Gram-positive mastitis-causing pathogens (Broadbent et al, 1989).

Preference focuses on nisin, although bacteria belonging to the genus Lactococcus are able also to produce other bacteriocins with economic potential. An example is lacticin 3147 , active in a wide range of $\mathrm{pH}$ and with a wide spectrum of action over Gram-positive bacteria. The genetic determinants for its synthesis are located in plasmids, so lacticin genes can be conveniently transmitted to different starter cultures of Lactococcus (Ross et al, 1999).

As it is active under physiological $\mathrm{pH}$, it has a great potential for use with medical purposes (Galvin et al, 1999). It has a bactericide mode of action against all Gram-positive bacteria tested so far, including food deteriorants as Clostridium sp, pathogenic microorganisms as Listeria monocytogenes, and those causing bovine mastitis Staphylococcus aureus and Streptococcus dysgalactiae (Ryan et al, 1998). It is also active on human pathogens as methicilin-resistant Staphylococcus aureus (MRSA), vancomicinresistant Enterococcus faecalis, penicillin-resistant Pneumococcus, Propionibacterium acne and Streptococcus mutans. These characteristics make lacticin 3147 very attractive for its potential application in the food industry, veterinary medicine, and eventually in the treatment of human diseases (Guinane et al, 2005).

Other bacteriocins

Class II acidocin CH5 is produced by Lactobacillus acidophilus, and has a restricted activity against Gram-positive bacteria. Chumchalova et al, (2004) have demonstrated its activity against eight strains of the genus 
Lactobacillus. Another acidocin, produced by $L$. acidophilus DSM 20079, has been characterized by Deraz et al (2005) as a one-component peptide of low molecular weight $(6.6 \mathrm{kDa})$, extremely heat-stable and active over a wide $\mathrm{pH}$ range, although with a narrow inhibitory activity spectrum.

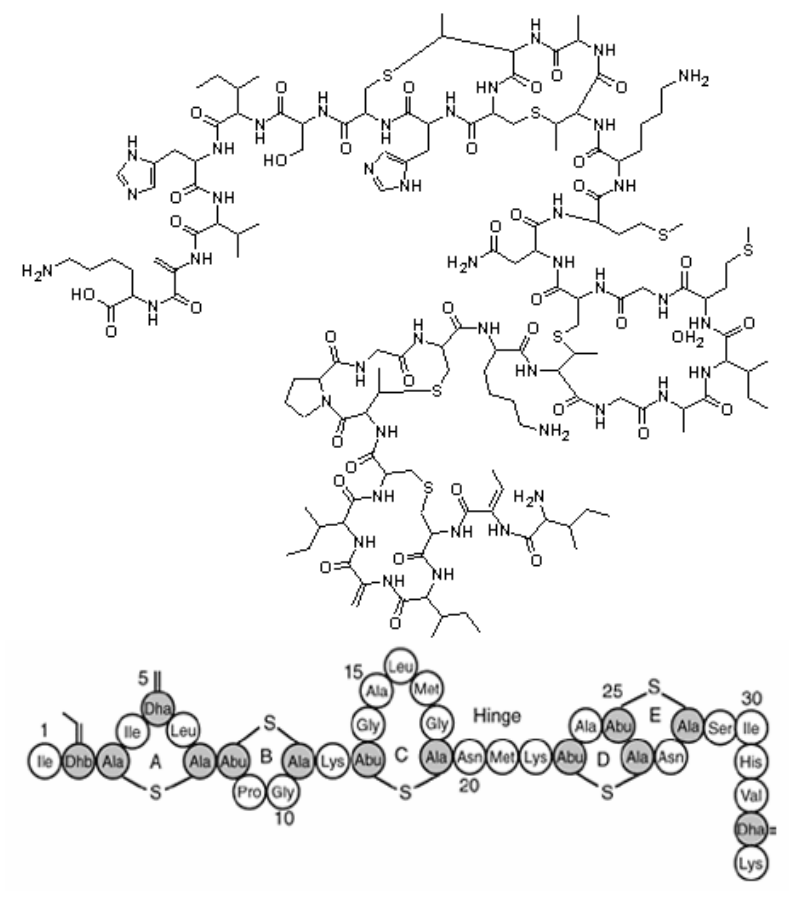

Figure 1 - Primary structure of nisin.

Another L. acidophilus bacteriocin is lactacin F, which is a proteinaceous heat-stable component and inhibitory for other lactobacilli as well as Enterococcus faecalis (Muriana and Klaenhammer, 1991).

Leuconostoc species have been associated with raw foodstuffs, dairy products and wine fermentation. Some have been identified and shown to produce bacteriocins. They include: Leuconostoc gelidum, Leuconostoc mesenteroides (Daba et al, 1991), Leuconostoc paramesenteroides and Leuconostoc carnosum (Geisen et al, 1993). Bacteriocin producing leuconostocs were isolated from vacuum packaged meat, retail lamb, goat's milk and cheddar cheese (Mackay et al, 1997).

Leucocin A, produced by Leuconostoc gelidum, has a molecular weight of approx. $4 \mathrm{kDa}$ (37 amino-acids), is one of a group of small antibacterial peptides produced by lactic acid bacteria. This group may include lactacin F (6.3
$\mathrm{kDa}, 57$ amino acids), pediocin $\mathrm{A}(2.7 \mathrm{kDa})$, and cloned bacteriocins (Hastings et al, 1991).

According to Morisset et al (2004), mesentericin Y105 is a 37-residue bacteriocin produced by Leuconostoc mesenteroides Y105 that displays antagonistic activity against Gram-positive bacteria such as Enterococcus faecalis and Listeria monocytogenes. It is closely related to leucocin A. Bacteriocins from Pediococcus species, designated as pediocins, were shown to be protein in nature and inhibitory to several other bacteria. Pediocin $\mathrm{F}$, one of the bacteriocins produced by $P$. acidilactici isolated from fermented sausage, is a small peptide, with a molecular weight of approx. $4,5 \mathrm{kDa}$ that has shown to be effective against many bacteria associated with food spoilage and food related health hazards. Pediocin F is reported to be sensitive to proteolytic enzymes, resistant to heat and organic solvents, and active over a wide range of $\mathrm{pH}$ (Osmanagaoglu et al, 1998). 
Table 1 - Bacteriocins of lactic acid bacteria and their main characteristics

\begin{tabular}{llll}
\hline Producing species & Bacteriocin & Spectrum of action & Characteristics \\
\hline Lactococcus lactis subsp. lactis & Nisin & Gram-positive bacteria & $\begin{array}{l}\text { Class I lantibiotic, 3,5 kDa, 34 amino-acids, } \\
\text { commercially available }\end{array}$ \\
Lacticin 3147 & $\begin{array}{l}\text { Clostridium sp } \\
\text { Listeria monocytogenes } \\
\text { Staphylococcus aureus } \\
\text { Streptococcus dysgalactiae } \\
\text { Enterococcus faecalis } \\
\text { Propionibacterium acne } \\
\text { Streptococcus mutans }\end{array}$ & $\begin{array}{l}\text { Class I two-component lantibiotic, 4,2 kDa, heat- } \\
\text { stable, active under acid and physiological pH }\end{array}$ \\
& Lactobacillus & $\begin{array}{l}\text { Class II bacteriocin, approx. } 5 \mathrm{kDa} \text {, narrow spectrum } \\
\text { of action }\end{array}$ \\
\hline Lactobacillus acidophilus & Acidocin CH5 & $\begin{array}{l}\text { Gram-positive bacteria } \\
\text { Lactobacillus }\end{array}$ & $\begin{array}{l}\text { Class II bacteriocin, forms high molecular weight } \\
\text { aggregates }\end{array}$
\end{tabular}

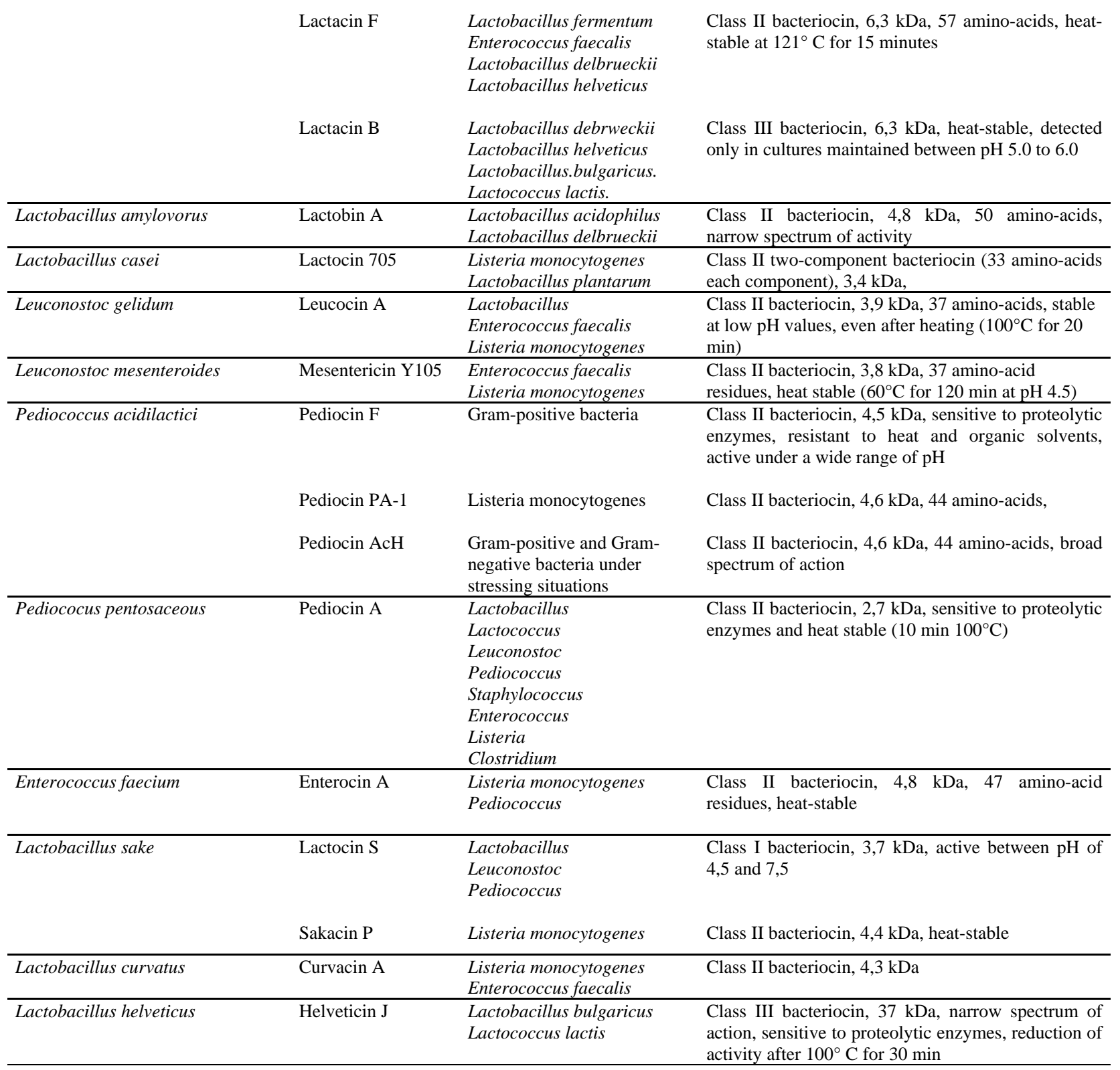


Enterococcus faecium CRL35, a strain isolated from regional Argentinean cheese, produces a bacteriocin called enterocin CRL35. It possess activity against the food borne pathogen Listeria monocytogenes, and by its efficiency, this peptide has potential as antimicrobial agent in foods (Minahk et al, 2000).

\section{Stability}

Some studies of characterization of bacteriocins show that these molecules can be active under certain ranges of temperature and $\mathrm{pH}$. Sensibility to proteolytic enzymes evidences the proteinaceous characteristic of bacteriocins (De Martins et al, 2003). Complete inactivation or significant reduction in antimicrobial activity of the bacteriocins ST28MS and ST26MS produced by Lactobacillus plantarum isolated from molasses was observed after treatment with proteinase $\mathrm{K}$, pronase, pepsin and trypsin. These bacteriocins remained stable after incubation for $2 \mathrm{~h}$ at $\mathrm{pH}$ values between 2.0 and 12.0. No decrease in antibacterial activity was recorded after $90 \mathrm{~min}$ at $100^{\circ} \mathrm{C}$ or $20 \mathrm{~min}$ at $121^{\circ} \mathrm{C}$ (Torodov and Dicks, 2005).

The thermotolerance feature might be related to the molecular structure of the bacteriocin, usually composed by small peptides without tertiary structure (Toro, 2005).

\section{Bacteriocin-like Substances}

Lactic acid bacteria are capable of producing other substances, known as bacteriocin-like substances (BLS). An example of this class of molecule is reuterin, produced by some strains of Lactobacillus reuteri during anaerobic fermentation of glycerol (Rodríguez et al, 2003; Pancheniak et al, 2006). It is water-soluble, active over a wide range of $\mathrm{pH}$ values and resistant to proteolytic and lipolytic enzymes, being a suitable compound for food biopreservation.

Lactobacillus plantarum TF711 isolated from raw Tenerife goat's cheese dy Hernández et al (2005) produced a bacteriocin-like substance with a molecular weight of $2,5 \mathrm{kDa}$, which was called plantaricin TF711. It was shown to be active against the Gram-positive bacteria Bacillus cereus, Clostridium sporogenes and Staphylococcus aureus, as well as against the Enterobacteriaceae Shigella sonnei and Klebsiella pneumoniae. It was stable to heat and to treatment with surfactants and organic solvents. Highest antimicrobial activity was found between $\mathrm{pH} 1$ and 9 .

Carnobacterium pscicicola L103 isolated from vacuum packed meat has shown the ability to produce a bacteriocin-like substance, which caused inhibition of six strains of Listeria monocytogenes isolated from salmon and from human origin (Schöbitz et al, 2003). No significant growth of the pathogen was observed at $4 \pm 2^{\circ} \mathrm{C}$ during 15 days, when compared to the salmon inoculated only with L. monocytogenes (Schöbitz et al, 2006).

Three strains of Lactobacillus ( $L$. plantarum, $L$. fermentum and L. acidophilus) isolated from Turkish dairy products showed inhibitory activity against Staphylococcus aureus, Escherichia coli and Yersinia enterocolitica due to bacteriocin-like substances. They were resistant to heat; the inhibitory activity of bacteriocin-like substances was not lost after 10 and $20 \mathrm{~min}$ at $100^{\circ} \mathrm{C}$ (Aslim et al, 2005).

The antagonistic activity of Lactobacillus sake 148 is due to the production of sakacin $\mathrm{M}$, a peptide of appox. 4,6 kDa, purified by lyophilization and gel filtration. The partially purified antagonistic activity of $L$. sake 148 was destroyed by treatment with proteolytic enzymes. However, it was resistant to heat, having D-values at 121, 135 and $150^{\circ} \mathrm{C}$ of $23.8,17.4$ and $15.2 \mathrm{~min}$, respectively.

\section{Isolation and Purification}

The first step for isolation of bacteriocins involves a screening of lactic acid bacteria from different sources, which may vary from plant material and food products to human or animal isolates. Moreno et al (1999) have isolated several strains of lactic acid bacteria from food products as cheese and milk. The antagonistic activity was detected through the well diffusion assay on agar plates (Toro, 2005). To avoid antagonism by hydrogen peroxide, catalase was added to the culture medium; phosphate buffer was added to the solid medium to exclude inhibition by organic acids. Additional tests in liquid medium are confirmatory and allow the determination of minimal inhibitory concentration.

Bacteriocins of lactic acid bacteria have been widely studied in recent years, however, there are relatively few studies that describe their chemical structure. This may be due to the many challenges associated with the purification of these antimicrobial peptides (Mackay et al, 1997). 
Various strategies for the purification of bacteriocins from complex cultivation broths have exploited their cationic and hydrophobic characteristics (Cheigh et al, 2004).

Usual methods for bacteriocins extraction are based on their affinity to organic solvents, their variation in solubility in concentrated salt solutions and at a given $\mathrm{pH}$ value. The presence of hydrophobic regions in bacteriocin molecules is essential for their activity against sensitive bacteria, since inactivation of microorganisms by bacteriocins depends on the hydrophobic interaction between the bacterial cells and bacteriocin molecules (Burlanek and Yousef, 2000).

Some bacteriocins appear in their native state as aggregates with high molecular mass (ca. 30-300 $\mathrm{kDa}$ ). These aggregates may mask partially or completely the antimicrobial activity of the bacteriocins during their purification and also induce errors in the determination of their molecular weight. This is especially true with highly non-polar low-molecular-weight bacteriocins, which easily interact with extracellular material of lysated cells (e.g., cell wall debris and micelles of lipotheicoic acids) and other non-polar compounds from the culture medium (Cintas et al, 2001).

In all these cases, macromolecular complexes may be disaggregated by using dissociating agents such as urea or SDS (Muriana and Klaenhammer, 1991), ultrafiltration (Muriana and Klaenhammer, 1987) or by eliminating lipid material by extractions with methanol-chloroform or ethanoldiethyl-ether (Contreras et al., 1997). Once the bacteriocins are recovered from the cell-free supernatants, they can be concentrated by techniques permitting separation of the fractions according to their size and/or physicochemical properties (Cintas et al, 2001).

\section{Methods of Purification}

Since bacteriocins are secreted into the culture medium, most strategies start with a step to concentrate bacteriocins from the culture supernatant, using for example diatomite calcium silicate (Coventry et al, 1996) or ammonium sulfate precipitation (Yang et al, 1992). Although these procedures are used principally to reduce the working volume, they do not provide a high degree of purification (Guyonnet et al, 2000). Therefore, subsequent steps by using preparative isoelectric focusing and/or multiple chromatographic separations, including cation exchange, gel filtration, hydrophobic interaction and reverse-phase liquid chromatography are necessary to achieve significant purification of bacteriocins. Usually, but not always, the yields obtained are low. This is probably due to the high number of steps in the protocol, leading to timeconsuming processes and subsequently low yields. To determine optimal parameters for the bacteriocin production, it is necessary to determine the ideal conditions of growth of the lactic strains and the composition of the culture medium. The medium usually contains a complexity of nutrients for optimal production of bacteriocins, but high contents of peptides might interfere in the purification process (Mackay et al, 1997).

An ideal protocol for bacteriocin production should be one that is applicable to large-scale purification, leading to bacteriocin yields higher than 50\% and purity around $90 \%$ (Schöbitz et al, 2006).

In general, for the non-lantibiotic bacteriocins, the methods involve growth in a suitable liquid nutrient medium under optimal conditions for bacteriocin production, removal of the cells followed by fractionated precipitation of the proteins from the culture supernatant by addition of ammonium sulfate. The precipitated proteins are subsequently dissolved in deionized water or in a weak buffer, and bacteriocin molecules are separated by use of different procedures including hydrophobic, ion-exchange, and size exclusion chromatography. Although these techniques have facilitated production of highly purified bacteriocin preparations, the final yield has generally been below $20 \%$ and involves several days of processing (Jack et al, 1995).

Many lactobacilli species have been identified as producers of bacteriocins. The origin of these species has mainly been from dairy and vegetable fermentations, vacuum-packaged meat products (Martins and Freitas, 2003) and from animal or human isolates (Mackay et al, 1997). Purification of bacteriocins was made by using ammonium sulfate precipitation, ion-exchange chromatography, hydrophobic interaction and reverse-phase HPLC.

The bacteria belonging to the genus Carnobacterium were initially recognized as nonaciduric lactobacilli. These bacteria are now differentiated from Lactobacillus by their inability to grow on acetate agar at $\mathrm{pH} 5.6$, their ability to 
grow at high $\mathrm{pH}$ (8.5-9.5) and their ability to produce L-lactate and oleic acid.

Bacteriocins producing strains were isolated from poultry, fish and vacuum-packaged meat. Among the carnobacteria, carnocin, carnobacteriocins BMl and B2 have been purified (Mackay et al, 1997). A bacteriocin-like substance produced by Carnobacterium pscicicola L103 was partially purified by ammonium sulfate precipitation and gel filtration on Sephadex G-25, followed by lyophilization, in order to test its activity against Listeria monocytogenes in vacuum-packaged meat (Schöbitz et al, 1999).

\section{Purification of class I bacteriocins}

Lactococci are widely employed in the dairy industry. Bacteria from this group are involved in the production of the lantibiotic nisin, lactococcins, lactostrepcins, diplococcins and others (Mackay et al, 1997; Moreno et al, 2000).

Cheigh et al (2004) have developed a simple onestep purification method, using expanded bed ionexchange chromatography, for the fractionation of nisin $\mathrm{Z}$ produced by Lactococcus lactis subsp. lactis A164. The purification from the unclarified A164 culture broth resulted in 31-fold purification with a $90 \%$ yield. According to this author, conventional purification methods are multi-step processes, requiring expensive equipments at each step, and may result in a significant loss of desired product. The overall reduction in the total number of purification steps, therefore, would lead to a higher product yield and be more cost-effective. In addition, these methods are usually timeconsuming, and unsuitable for large-scale purification of bacteriocins (Coughlin and Crabb, 2002).

Suárez et al (1997) have proposed a single-step method for the purification of nisin, based on an immunoafinity chromatography. An immunoadsorption matrix was developed by direct binding of anti-nisin A monoclonal antibodies to $N$-hydroxysuccinimide-activated Sepharose. The purification procedure showed to be rapid and reproducible and rendered much higher final yields of nisin than the traditional described methods. According to the author, the specific monoclonal antibodies against nisin A have provided a method that is able to purify this bacteriocin even from a complex medium such as MRS broth without unspecific adsorption. The procedure is simple, rapid, highly specific, reproducible, and inexpensive, permitting the purification of nisin to homogeneity in a single step. These characteristics allow the development of a scale-up process for the purification of this bacteriocin.

Acidocin $\mathrm{CH} 5$, produced by L. acidophilus, was purified by using combinations of chromatographic methods based on hydrophobic and cation exchange principles (Chumchalova et al, 2004). Acidocin D20079, produced by $L$. acidophilus DSM 20079, was purified by ammonium sulphate precipitation followed by sequential cation exchange (Carboxymethyl Sepharose column), dialysis and hydrophobic interaction chromatography (Octyl Sepharose column), followed by electrophoresis (SDSPAGE) (Deraz et al, 2005).

Lactocin $\mathrm{S}$, a $3,7 \mathrm{kDa}$ bacteriocin produced by Lactobacillus sake L45, has been purified to homogeneity by precipitation of the cell-free supernatant with ammonium sulfate $20 \%$, ion exchange (Q-Sepharose anion exchange column and S-Sepharose cation exchange column), hydrophobic interaction (Phenyl Sepharose CL-4B column) and reverse-phase chromatography and gel filtration (using an FPLC system) (Mørtvedt et al, 1991).

\section{Purification of class II bacteriocins}

Several pediococci have an important role in vegetable and meat fermentations, where they are responsible for the production of acid and flavor development. Bacteriocins produced by pediococci have a relatively broad spectrum of activity against Gram-positive bacteria and are designated pediocins. Pediocins are produced mainly by Pediococcus pentosaceous (Piva et al, 1994) and Pediococcus acidilactici (Bhunia et al, 1987; Mackay et al, 1997). Vinema et al (1997) have purified pediocin PA-1, produced by Pediococcus acidilactici through ethanol precipitation; preparative isoelectric focusing after addition of ampholytes, Tween 20 and glycine; and ultrafiltration; the purified sample was subjected to tricine SDS-PAGE. Very pure bacteriocin preparations were obtained with this method, not involving chromatographic columns, with yields between 30 and $40 \%$ (other purification protocols have obtained yields between 0,5 and $1 \%$ ).

Several class II bacteriocins (enterocin A, sakacin $\mathrm{P}$, and curvacin $\mathrm{A}$ ) were purified by ammonium sulfate precipitation followed by three chromatography steps using ion exchange, hydrophobic interaction, and reversed phase 
chromatography (Eijsink et al, 1998). Very large volumes of washing buffer (up to 40 times the column volume) were used for the washing steps during ion-exchange and hydrophobic interaction chromatography, in opposition to the previously described methods. This small change in the protocol contributed considerably to purity.

Lactobin A, produced by $L$. amylovorus, was purified from the cell-free supernatant by saturation with ammonium sulfate (35\%), followed by gel filtration chromatography and methanol-chloroform extraction (to remove fatty acids contaminants); ion-exchange, hydrophobic interaction and reverse-phase chromatography in a FPLC system (Contreras et al, 1997).

Another bacteriocin is lactacin B from $L$. acidophilus, was purified by ion-exchange chromatography (Carboxymethyl Sephadex column), ultrafiltration, and successive gel filtrations in the presence of $8 \mathrm{M}$ urea and then $0,1 \%$ sodium dodecyl sulfate (Barefoot and Klaenhammer, 1984).

Lactacin F, a 2,5 $\mathrm{kDa}$ peptide, was purified by ammonium sulfate precipitation, gel filtration, and high-performance liquid chromatography in reversed phase (Muriana and Klaenhammer, 1991).

Guyonnet et al (2000) developed a three-step method for the purification of mesentericin Y105, produced by Leuconosto. mesenteroides Y105. The purification procedure replaced the ammonium sulfate precipitation for cation exchange chromatography. The temperature and time of sterilization of the culture medium were reduced, in order to minimize the amount of hydrophobic, colored contaminants present in the media. The culture supernatant was applied to a carboxy-methyl-cellulose-filled column ( 2.5 by 18 $\mathrm{cm}$ ), followed by a $\mathrm{C}_{18}$ cartridge and $\mathrm{C}_{8}$ Kromasil analytical HPLC column.

The amount of purified mesentericin Y105 obtained from $100 \mathrm{ml}$ of culture supernatant was $120 \mu \mathrm{g}$, which corresponds to a yield of $60 \%$ of recovered activity, indicating an initial amount of $2 \mathrm{mg}$ of bacteriocin per liter in the culture medium.

Leuconostoc gelidum produces a bacteriocin, leucocin A-UAL 187, which has been purified by ammonium sulfate or acid ( $\mathrm{pH} 2,5)$ precipitation, hydrophobic interaction chromatography, gel filtration, and reversed-phase high-performance liquid chromatography with a yield of $58 \%$ of the original activity (Hastings et al, 1991) resulting in a good yield. Similar yields were obtained when these procedures were used for the isolation of lantibiotics. Morisset et al (2004) have also purified mesentericin Y105 using this three-step protocol. The purity level of peptides was more than $95 \%$, according to the high-pressure liquid chromatography elution profile of the purified extracts.

Enterococcus faecium has shown to be a bacteriocin producer. Enterocin ON 157 produced by $E$. faecium NIAI 157 isolated from spoiled grass silage has been purified by Ohmomo et al (2000) using a combination of ultrafiltration, ammonium sulfate precipitation and cationexchange chromatography. It is a small peptide, with a molecular weight of $2,5 \mathrm{kDa}$, stable under low $\mathrm{pH}$ vales $(2,0-5,0)$. It was completely inhibited by proteolyic enzymes and showed strong activity against Listeria monocytogenes, but no activity against Gram-negative bacterial species.

A method involving solvent extraction was developed by Burlanek and Yousef (2000) to concentrate lacidin from the culture broth of Lactobacillus acidophilus OSU133. The new method considers the amphiphilic property of bacteriocins, and concentrates the bacteriocin at the interface of immiscible liquids (in this case, chloroform and the aqueous culture of the producing bacterium). Compared with other extraction procedures, this method effectively recovers higher bacteriocin yield and results in relatively clean preparations.

Among the lactococcins, is lactococcin B, a bacteriocin with approximately $5 \mathrm{kDa}$ of molecular weight produced by Lactococcus lactis, was purified by a method that does not involve chromatography columns. Instead, the cell-free supernatant of the culture was subjected to ethanol precipitation and preparative isoelectric focusing (freeze-drying) after addition of ampholytes, Tween 20 and glycine. Ultrafiltration was used and the purified sample subjected to tricine SDSPAGE (Vinema et al, 1997).

\section{Purification of class III bacteriocins}

Helveticin J, a peptide produced by Lactobacillus helveticus 481 is a class III bacteriocin, sensitive to proteolytic enzymes and heat. It was purified by Joerger and Klaenhammer (1986) using ammonium sulfate precipitation; the pellet was ressuspended in sodium acetate buffer and dialysed against the same buffer. The sample was 
applied to a Sephadex column for gel chromatography, followed by SDS-page.

Lactobacillus acidophilus produces a bacteriocin called lactacin B, which has been purified by ionexchange chromatography with a carboxymethyl Sephadex column, ultrafiltration, and successive gel filtrations in the presence of $8 \mathrm{M}$ urea and then $0,1 \%$ sodium dodecyl sulfate (Barefoot et al, 1984).

\section{Other considerations}

According to Mackay et al (1997), there is a number of important considerations to be made when purifying bacteriocins, like the strain, composition of the culture medium, and purification technology among others. The production of many bacteriocins seems not to be inducible and relatively low tites of activity are detected in broth cultures. For purification purposes then, it is necessary to do production studies and to start with large batches of cultures prior to the purification of these peptides. The conditions of incubation, particularly temperature, $\mathrm{pH}$ and time strongly influence the effective yield of active bacteriocin (Yang and Ray, 1994). For each producer organism the optimal conditions need to be determined empirically.

Optimal nisin production usually requires complex media and well-controlled factors such as temperature and $\mathrm{pH}$ (De Vuyst, 1995; Kim et al, 1997). A higher initial sucrose concentration leads to the repression of catabolism and inhibits nisin biosynthesis in batch culture (De Vuyst and Vandamme, 1992). To maximize the productivity of nisin, it is necessary to determine the most appropriate sucrose concentration ( $\mathrm{Lv}$ et al, 2005). According to this author, nisin production increases with cell growth, but reaches maximum values when cell growth ceases. The decrease in nisin titers may be caused by cell adsorption or its destruction by non-specific proteolytic enzymes released during cell lysis.

The utilization of anticaking, clarifying and filtration agents may be used after the fermentation process to ease the purification of the bacteriocin produced. Coventry et al (1996) used a food-grade diatomite calcium silicate anticaking agent for the extraction of pediocin PO2, brevicin 286, and piscicolin 126 from fermentation media by adsorption to a porous calcium silicate (MicroCel). All four bacteriocins were adsorbed, with little activity detected in the supernatants.
Since the major objective of most of these studies has been the preparation of highly purified bacteriocins, the low yield, relatively lengthy processing time, and requirement for costly instrumentation in these purification protocols were not a primary consideration (Jack et al, 1995).

Yang et al (1992) have proposed a different method for large-scale purification that involves adsorption of the bacteriocin to the cell wall of the producing cell. Pediocin $\mathrm{AcH}$ produced by Pediococcus acidilactici, nisin produced by Lactococcus lactis subsp. Lactis ATCC 11454, leuconocin Lcm 1 produced by Leuconostoc carnosum Lm 1 and sakacin A produced by Lactobacillus sake Lb 706 were successfully purified by this procedure. The method was based on observations that the fully processed bacteriocin molecules are: excreted by the producer cells; are cationic; adsorb to the cell surface of the producer strains (and other grampositive bacteria); adsorb in a $\mathrm{pH}$-dependent manner, high (ca. 90\%) at about $\mathrm{pH}$ 6,0 and low (ca. $1 \%$ ) at about $\mathrm{pH} 2,0$; and adsorb efficiently to heat-killed cells. At pH 6,0 the bacteriocins are adsorbed to the producing cells. In the presence of a low $\mathrm{pH}(1,5-2,0)$, these bacteriocins are released. After that, a SDS-PAGE analysis of the preparation was made. The recovery for pediocin $\mathrm{AcH}$, nisin and leuconocin Lcm 1 was over $90 \%$. The method described produced dry preparations of bacteriocins that were highly potent for pediocin $\mathrm{AcH}$ and nisin, and also pure.

Osmanagaoglu et al (1998) have successfully purified pediocin F, produced by Pediococcus acidilactici, using the same method, as well as Castellano and Vignolo (2006), who have purified lactocin AL705 from the supernatant culture of Lactobacillus curvatus with this methodology. Vignolo et al, (2000) have successfully purified lactocin 705 produced by $L$. casei CRL705 isolated from dry-sausages using this adsorptiondesorption $\mathrm{pH}$-dependent method, followed by RP-HPLC chromatography and SDS-PAGE electrophoresis.

The great challenge is to improve high scale production.

\section{Immunity}

According to Koponen (2004) the bacterial cell may present some immunity mechanisms, here defined as the ability of the cell of protecting itself 
against a bacteriocin produced by its own metabolism.

Both cell wall constitution and membrane lipid composition have been demonstrated to be involved in bacteriocin action as well as bacteriocin resistance. The variation of susceptibility of Gram-positive bacteria towards bacteriocins is considerable. The inhibitory action of these antimicrobial peptides can vary between different genera, species of the same genera, identical species, and even identical cultures under different environmental conditions (Castellano et al, 2001).

Two types of immunity have been described for lantibiotics, one reliant on a specific immunity protein, LanI, while the other depends on a separate multi-component transporter (LanEFG). Some lantibiotic clusters have only the single immunity protein, whereas others, such as nisin, possess both mechanisms (Engelke et al, 1994). Class II bacteriocins generally have a single-cell membrane-associated immunity protein that provides complete immunity (Deegan et al, 2006).

This mechanism depends mainly on a bacteriocinspecific immunity protein, which is expressed concomitantly with the bacteriocin, and does not require the processing and transport system necessary for exporting the bacteriocin (Cintas et al, 2001). This immunity can be activated in various ways against pore-formation bacteriocins as nisin. Adsorption of the bacteriocin to the membrane can be inhibited; bacteriocins adsorbed by the membrane can be translocated back to the environment or degradated in the cytoplasm of the cell. The process of the pore formation in the membrane can be inhibited by specific interactions of the bacteriocin with membrane proteins associated to immunity. Also, the pore may be unstabilized or blocked by an immunologic protein.

It is probable that for each bacteriocin there may be a relatively specific membrane protein, whose function is to translocate a precursor form of the bacteriocin across the cytoplasmic membrane to the outside of the cell (Jack et al, 1995).

Strains producing one specific bacteriocin may or may not be sensitive to other similar bacteriocins (Jack et al, 1995). Resistance to the activity of a bacteriocin can also develop when a normally sensitive strain is grown in the presence of a bacteriocin. Some strains of bacteria can produce more than one type of bacteriocin, as well as the corresponding specific immunity proteins, responsible for self-protection to each of the produced bacteriocins.

\section{Mode of Action}

These peptides are usually effective against Grampositive microorganisms. Bacteriocins of lactic acid bacteria may be inefficient to inhibit Gramnegative organisms because the outer membrane hinders the site for bacteriocin action, which is the cell membrane (De Martinis et al, 2001; Morisset et al, 2004).

Different mechanisms of action have been proposed for bacteriocins: alteration of enzymatic activity, inhibition of spore germination and inactivation of anionic carriers through the formation of selective and non-selective pores (Abee, 1995; Martinez and De Matins, 2006).

LAB bacteriocins can work via different mechanisms to exert an antimicrobial effect, but the cell envelope is generally the target. The initial electrostatic attraction between the target cell membrane and the bacteriocin peptide is thought to be the driving force for subsequent events. (Deegan et al, 2006).

Bacteriocins may possess a bactericidal or bacteriostatic mode of action on sensitive cells, this distinction being greatly influenced by several factors such as bacteriocin dose and degree of purification, physiological state of the indicator cells and experimental conditions (Cintas et al, 2001).

According to Jack et al (1995), at least for the nonlanthionine-containing bacteriocins, the increased antibacterial activity observed at low $\mathrm{pH}$ may be the result of any one of a number of factors, including the following: (i) aggregation of hydrophilic peptides is less likely to occur, and, thus, more molecules should be available to interact with sensitive cells; (ii) fewer molecules will remain bound to the wall, making more molecules available for bactericidal action; (iii) hydrophilic bacteriocins may have an enhanced capacity to pass through hydrophilic regions of the cell wall of the sensitive bacteria; and (iv) interaction of the non-lanthionine-containing bacteriocins with putative membrane receptors may be inhibited at higher $\mathrm{pH}$ values.

Several features of the mode of action of the nonlanthionine-containing bacteriocins of grampositive bacteria require further explanation: (i) the reason why, for two sensitive strains, one undergoes lysis following treatment with a 
particular bacteriocin while the other does not is not known; (ii) for a bacteriocin to come into contact with the cytoplasmatic membrane of sensitive cells, the molecules must firstly pass through the cell wall; the mechanism of this translocation remains to be understood; and, finally, (iii) there is evidence that non-lanthioninecontaining bacteriocin molecules may be adsorbed on the surface of most gram-positive bacterial cells, including sensitive, resistant, and producer strains; the influence of this is not yet fully understood (Jack et al, 1995).

The cell wall of gram-positive bacteria allows passage of relatively large molecules, so that there is unlikely to be a requirement for bacteriocin receptors analogous to those in the outer membranes of gram-negative cells. Anionic cell surface polymers like teichoic acid and lipoteichoic acid may be important in the initial interaction of cationic bacteriocins of Grampositive bacteria (Jack et al, 1995).

Initially, nisin was thought to act as a surfactant because of its cationic nature and because treatment of cells with nisin caused leakage of UV-absorbing material (Jack et al, 1995).

According to González-Martínez et al (2003), it is possible that classes I and II use the same mechanisms of action. Peptides bond to the plasmatic membrane through electrostatic interactions with phospholipids charged negatively. So, it gets into the membrane with a reorientation that depends on the membrane potential, which is driven by the $\mathrm{pH}$ and phospholipidic composition. The monomers of bacteriocin form proteic aggregates that result in the pore formation with the consequent leave of ions (mainly potassium and magnesium), loss of the proton-motriz force, and exit of ATP and amino-acids. The proton motriz-force has a fundamental role in ATP synthesis, in active transport and in the bacterial movement; therefore, the synthesis of macromolecules is inhibited, as well as the production of energy, resulting in cell death (Bruno and Montville, 1993).

Pore formation and the consequent loss of membrane integrity induces a passive efflux of small molecules, such as potassium and phosphate ions, amino acids and ATP, through the lipid bilayer, which results in the reduction or dissipation of the proton motive force, or at least of one of its components: $\mathrm{D} \psi$ (membrane potential) and $\mathrm{DpH}$ (pH gradient) (Cintas et al, 2001).
In class I, nisin does not require a receptor on the cell membrane, since it recognizes the phospholipidic composition of the cell. Lactococin $\mathrm{A}$ and lactoestrepcin require binding to a specifc receptor.

For class IIa bacteriocins, it is believed that the amino-terminal region has an important role in the ability to recognize cell membrane components, and they act by permeabilizing the membrane of their target cells (Eijsink et al, 1998). Studies on the mode of action of these bacteriocins indicate that antimicrobial activity does not require a specific receptor and is enhanced by a determined membrane potential (Ennahar et al, 2000). In class $\mathrm{IIb}$, plantaricins EF and $\mathrm{JK}$ depend on the interaction between the peptides "a" and " $b$ " for the pore formation and consequent dissipation of the membrane potential. In class III, which includes bacteriocins with a high molecular weight, the mechanism of action is unknown, requiring more studies for its elucidation (González-Martínez et al, 2003).

It is likely that the secondary structures of the active peptides have an important role, since the $\alpha$ helical and $\beta$-folded structures suggest an oligomerization of the monomers in the membranes, according to a mechanism of pore formation denominated "barrel-stave", with the hydrophobic sides inserted on the membrane and the hydrophilic sides forming the pore itself.

Lactocin 705 is a class IIb non-lantibiotic bacteriocin, whose activity depends upon the complementation of two peptides (named Lac $705 \alpha$ and Lac705 $\beta$ ) of 33 amino-acid residues each (Castellano et al, 2003). A study made by Cuozzo et al (2001) has shown that Lac705 $\beta$ is the active component of lactocin 705 on cell membrane, while the peptide Lac705 $\alpha$ is involved in receptor recognition on the sensitive cells. It is suggested that lactocin 705 acts as a complex of Lac705a and Lac705 $\beta$ (ratio 1:4) peptides and exert its action through interaction with cell wall-associated or membrane-associated binding sites in the sensitive cells. According to this author, it is possible that the specificity of this porin complex is given by the Lac705 peptide; its net positive charge at the $14 \mathrm{C}$-terminal amino acids would neutralize the negative charge of teichoic and lipoteichoic acids in the cell wall of sensitive cells, and interact specifically and competitively with some target cell entity, allowing the Lac705 $\beta$ 
peptide to form membrane pores, which increases membrane permeabilization and causes cell death. A study made by McAuliffe et al (1998) shows that the broad host-range lacticin 3147 is a twocomponent bacteriocin, membrane-active, that is hydrophobic in nature. The author proposes that lacticin 3147 forms pores which allow $\mathrm{K}^{+}$and phosphate to leak; the resulting change in electrical charge across the membrane causes the immediate dissipation of the $\Delta \psi$ component (membrane potential) of the proton-motriz force. In an attempt to recover these ions, the cells use phosphate bond-dependent transport, resulting in rapid ATP hydrolysis and leading to cell death. The presence of a proton-motriz force promotes the interaction of the bacteriocin with the cytoplasmatic membrane, leading to the formation of pores at low lacticin 3147 concentrations. These pores were shown to be selective for $\mathrm{K}^{+}$ions and inorganic phosphate. The loss of these ions results in immediate dissipation of the membrane potential and hydrolysis of internal ATP, leading to an eventual collapse of the $\mathrm{pH}$ gradient at the membrane, and ultimately to cell death. Lacticin 3147 does not cause immediate dissipation of the $\Delta \mathrm{pH}$ of sensitive cells, as the membrane does not become permeable to $\mathrm{H}^{+}$ions.

\section{Bacterial resistance to bacteriocins}

It is generally believed that the increased resistance to bacteriocins of mutant strains is caused by alterations in the cell envelope, including changes in the fatty acid composition of the membrane (Vignolo et al, 2000). The mechanism of resistance has not been fully established, but has been attributed to cell membrane changes or the interruption of genes encoding the phosphotransferase system (PTS) permeases (Schöbitz et al, 2003). It is suggested that a spontaneous resistance to nisin can develop as a consequence of an alteration in the cell surface or molecular components of the cell membrane that interact with the bacteriocin.

Resistance to $\mathrm{LAB}$ bacteriocins has been reported for L. monocytogenes, Staphylococcus aureus, Clostridium botulinum and Bacillus cereus. Vignolo et al (2000) have reported resistant Listeria monocytogenes and L. innocua to nisin, lactocin 705 and enterocin CRL35. Resistance may result probably from alteration of bacterial membrane composition, destruction of the bacteriocin by proteases or altered receptors (Martinez and De Martinis, 2005).

\section{Genetics}

The microbial genetics has contributed to the knowledge and improvement of LAB and the production of metabolites (Parada, 1985).

The genes responsible for bacteriocin production are frequently associated with mobilisable elements, or in the chromosome in association with transposons or plasmids (Belkum et al, 1989). The low-molecular-weight bacteriocins of grampositive bacteria generally appear to be translated as pre-peptides that are subsequently modified to form the mature biologically active (bactericidal) molecules (Buchman et al, 1998). Specific auxiliary functions required by bacteriocinproducing cells include mechanisms for extracellular translocation of the bacteriocin and for self-immunity to the bactericidal activity of the molecule (Jack et al, 1995).

As is the case for most bacteriocins, the lantibiotics are initially synthesized with an $\mathrm{N}$ terminal leader peptide. In general, the pre-peptide (generically designated LanA) is modified by the action of other proteins encoded by the bacteriocin gene cluster before export. (Deegan et al, 2006).

The nisin structural gene, nisA, has likewise been cloned and sequenced and found to be part of a polycistronic operon (Kaletta and Entian, 1989; Kuipers et al, 1993). Three additional genes lie downstream: nisB, nisT, which may be involved in nisin transport, and also nisC (Dodd et al, 1990). In addition, nis $C$ overlaps nis $T$. However, because of the presence of three possible translation initiation sites, the exact amount of overlap is presently unknown (Jack et al, 1995).

$N i s B$ contains several putative transmembrane helical regions and appears to bind to artificial phospholipid vesicles; leading to the suggestion that it is membrane bound and that nisin biosynthesis occurs at the cytoplasmatic membrane (Engelke et al, 1992). Other genes present in the nisin operon include nisI, nisR, and nisP. NisI is thought to encode a lipoprotein involved in nisin immunity, and nisP appears to be involved in the regulation of nisin biosynthesis (Vandermeer et al, 1993).

The genes required for the processing and export of Class II bacteriocins differ somewhat from those for lantibiotics due to the absence of posttranslational modifications (Deegan et al, 2006). 
The structural genes encoding many of the currently characterized non-lanthionine-containing bacteriocins have been located on plasmids (Jack et al, 1995).

In most bacteriocin operons, the genetic determinants associated to the production of biologically active bacteriocins include: (i) the structural gene encoding the pre-pro-bacteriocin; (ii) the gene codifying the immunity protein; (iii) the genes responsible for processing and transport of the bacteriocin, and, in some cases, (iv) the genes encoding the enzymes involved in posttranscriptional modifications (Cintas et al, 2001).

Bacteriocin genes are generally linked and may be located on plasmids, which may be conjugative or not, or in the bacterial chromosome, often integrating a composed transposon (Jack et al., 1995).

In most bacteriocin operons characterized so far, potential immunity genes have been identified next to, immediately downstream and with the same polarity than the bacteriocin structural gene (Cintas et al, 2001). Quiao et al (1997) have isolated a strain of Lactobacillus lactis that was highly resistant to nisin, but showed an increased production of this bacteriocin.

Peptide structure-function studies will help to reveal the molecular basis of the specificity of bacteriocin targeting and mode of action. Once the various ethical and regulatory hurdles are crossed, the path should be clear for commercial applications of starter cultures that produce a wide range of antibacterial peptides, and this in turn should bring about a significant reduction in the usage of potentially toxic nitrites in food preservation and should improve the safety of fermented foods (Jack et al, 1995).

Increased understanding of the mechanisms involved in bacteriocin regulation, processing, translocation, and immunity should facilitate attempts to optimize bacteriocin production and may further open the way to directed in vitro modifications in their antibacterial spectra (Jack et al, 1995).

Since techniques now available for the sitedirected mutagenesis of bacteriocin structural genes (Kim et al, 1998) and with the help of genomics and proteomics, the possibility of constructing new families of designed peptides with enhanced antimicrobial activity or improved stability and specificity characteristics has become a real possibility.

\section{Applications in food preservation}

Biopreservation systems such as bacteriocinogenic LAB cultures and/or their bacteriocins have received increasing attention, and new approaches to control pathogenic and spoilage microorganisms have been developed (Ross et al, 1999).

Some lactic acid bacteria (LAB) demonstrated antagonism towards pathogenic and spoilage organisms.

Although bacteriocins are produced by many Gram-positive and Gram-negative species, those produced by $\mathrm{LAB}$ are of particular interest to the food industry, since these bacteria have generally been regarded as safe.

Bacterial fermentation of perishable raw materials has been used for centuries to preserve the nutritive value of food and beverages over an extended shelf life (Deegan et al, 2006).

Despite the several methods other than bacteriocins are employed for the preservation of food/beverages, an increasingly, health conscious public may seek to avoid foods that have undergone extensive processing or which contain chemical preservatives.

The production of bacteriocins by $\mathrm{LAB}$ is advantageous for survival of the producing bacteria in a competitive ecological niche; therefore, they could be exploited by the food industry as a tool to control undesirable bacteria in a food-grade and natural manner, which is likely to be more acceptable to consumers (Deegan et al, 2006).

Among the lactic acid bacteria, a high diversity of bacteriocins are produced and several have been patented for their applications in foods. To date, the only commercially produced bacteriocins are the group of nisins produced by Lactoccocus lactis, and pediocin PA-1, produced by Pediococcus acidilactici (Schöbitz et al, 2006).

The lytic ability of bacteriocins like nisin and lacticin 3147 might be explored in the acceleration of cheddar cheese ripening. Cell lysis of the starter culture is advantageous for improved flavor development (Guinane et al, 2005).

Minimally processed refrigerated foods have been gaining consumer acceptance in the last years due to their natural appeal. However, the microbiological safety of these foods is of concern due to the possible presence of non-proteolitic toxic strains of Clostridium botulinum, able to grow at $4^{\circ} \mathrm{C}$, and the post-processing contamination with psychrothophic pathogens, 
such as Listeria monocytogenes (De Martinis et al, 2001; Schöbitz et al, 2006).

Listeria monocytogenes is a pathogenic bacterium that has been involved in several foodborne outbreaks worldwide and causes special concern with regard to food safety due to its psycrotrophic and ubiquitous characteristics. The presence of this pathogen in fermented sausages and in vacuumpackaged meat products (Chung et al, 1989) is of particular interest for food safety, as these two groups of meat are frequently eaten without reheating (Vignolo et al, 1996). This pathogen has shown to be able to survive at $\mathrm{pH}$ as low as 3.6 in foods and in salt concentration of up to $10 \%$, in the presence of surfactants, sanitizers and after several cycles of freezing and thawing (Martinez and De Martins, 2006), being a serious risk.

A study made by Martinez and De Martinis (2005) has shown that at $8^{\circ} \mathrm{C}, L$. monocytogenes was inhibited by bacteriocin of Lactobacillus sakei 1 and the antimicrobial peptide remained stable during all the experiment (10 days). At $15^{\circ} \mathrm{C}$, the antilisterial activity of $L$. sakei 1 was partially lost, which is a limitation for food industry, if bacteriocin is to be applied as an additional hurdle for food preservation.

\section{Bacteriocins mode of use}

There are at least three ways in which bacteriocins can be incorporated into a food to improve its safety, i.e., using a purified/semi-purified bacteriocin preparation as an ingredient in food, by incorporating an ingredient previously fermented with a bacteriocin-producing strain, or by using a bacteriocin-producing culture to replace all or part of a starter culture in fermented foods to produce the bacteriocin in situ (Deegan et al, 2006).

Bacteriocins can be incorporated into foods as a concentrated, though not purified, preparation made with food-grade techniques. When investigating novel candidates, there are many considerations that will determine their usefulness in food systems. One of the most significant criteria is the ability to withstand thermal processing. Thermal processing is used extensively within the food manufacturing process and can have adverse effects on the bio-active capability of a bacteriocin, potentially rendering it less effective. The chemical and physical properties of a food, e.g. $\mathrm{pH}$, and fat content, can also have a significant role in the suitability of a particular bacteriocin.
Some food ingredients might interfere with the bacteriocin activity. A study made by Vignolo et al (1998) indicated that the use of lactocin 705 to control L. monocytogenes was less effective in the presence of curing ingredients such as sodium chloride, sodium nitrite, ascorbic acid, alginate and sodium lactate. Although lactocin 705 was shown to be a successful inhibitor of the pathogen, the presence of sodium chloride changed the inhibition from a bactericidal to a bacteriostatic one.

Schillinger et al (2001) have studied the combination of nisin and a protective culture against Listeria monocytogenes in tofu, a nonfermented soybean product with a relatively high $\mathrm{pH}$, which may be contaminated during processing with spoilage or pathogenic bacteria including $L$. monocytogenes. The results were significantly better when nisin was added during the manufacture of tofu than when it was added as a solution in the final product. The study also showed that the combination of nisin with nisinresistant mutants of Lactobacillus sakei $\mathrm{Lb} 706$ or Enterococcus faecium BFE 900 was more effective in suppressing growth of $L$. monocytogenes Scott A than nisin alone. The application of the protective cultures alone did not result in a successful suppression of Listeria growth in tofu at low temperature.

Hurdle technology refers to the manipulation of multiple factors (intrinsic and extrinsic) designed to prevent bacterial contamination or control growth and survival in food (Deegan et al, 2006).

A combination of preservation methods may work synergistically or at least provide greater protection than a single method alone, thus improving the safety and quality of a food (Martinez and De Martins, 2005). The application of bacteriocins or bacteriocin-producing LAB strains in food has a potential use as part of the hurdle technology, since bacteriocins have shown synergies with other treatments and could be used to improve food safety. Although the nature of the Gram-negative cell wall restricts the activity of LAB bacteriocins, bacteriocins may be used in combination with other treatments to increase their effectiveness (Deegan et al, 2006).

A bacteriocin alone in a food is not likely to ensure satisfactory safety. This is of particular significance with regards to Gram-negative pathogenic bacteria that are protected by the presence of an outer membrane. When the outer membrane is impaired by agents such as the food- 
grade chelating agent ethylene diamine tetraacetate (EDTA), which acts by binding to $\mathrm{Mg}^{2+}$ ions in lipopolysaccharide; the outer membrane is disrupted, rendering Gram-negatives sensitive to bacteriocins (Deegan et al, 2006).

Bioactive packaging is a further potential application in which bacteriocins or the producing strains can be incorporated into packaging destined to be in contact with food. (Castellano and Vignolo, 2006; Schöbitz et al, 2006; De Martins et al, 2003).

Liserre et al (2002) obtained good results when packing meat products using a bacteriocinproducer strain of Lactobacillus sake synergically with modified atmosphere packing. This system combines the preservation function of bacteriocins with conventional packaging materials, which protects the food from external contaminants.

Spoilage of refrigerated foods usually begins with microbial growth on the surface, which reinforces the attractive use of bacteriocins being used in conjunction with packaging to improve food safety and improve shelf life.

In addition to the hurdle represented by low temperature and vacuum packaging, the use of the bioprotective culture L. curvatus CRL705 as well as its bacteriocins lactocin 705 and AL705 in fresh meat will ensure its microbiological safety (Castellano and Vignolo, 2006).

One of the concerns regarding the use of bacteriocins is the development of highly tolerant and/or resistant sensitive strains (Parada et al, 1980; Rekhif et al, 1994; Rasch and Knochel, 1998; Guinane et al, 2006). This induction of bacteriocin-resistant or tolerant strains and mutants may pose further problems in the use of bacteriocins in biopreservation.

\section{Resistance to bacteriocins}

An important aspect to take into consideration in relation to the commercial use of bacteriocins is the tolerance or resistance of certain pathogenic bacterial species that are normally sensitive, such as $L$. monocytogenes, since it may compromise the antibacterial efficiency of these compounds (Schöbitz et al, 2003).

From a practical point of view, considering the difference in the kinetics of inhibition and crossresistance of the survivors, it is to be expected that the combined use of nisin plus one of other bacteriocins would result in more efficient inhibition of Listeria (Vignolo et al, 2000). Bouttefroy and Milliere (2000) have combined nisin and curvacitin 13 to avoid the development of resistant strains of this genus.

The use of strains that produce multiple bacteriocins could be advantageous to limit the potential emergence of bacteriocin-resistant populations. Resistance can occur naturally and it has been reported especially with regards to Class IIa bacteriocins such as pediocin PA-1 and mesentericin Y105 among others (Deegan et al, 2006).

Given the manner in which bacteriocins are likely to be used in food, i.e. as one of a number hurdles, it is unlikely that the food industry will see the emergence of bacteriocin-resistant bacteria in the extent to which antibiotic-resistant pathogens have emerged in hospitals. However, the utilization of double bacteriocin producing strains would provide an additional barrier to ensure that the emergence of resistant populations is even less likely.

Despite of their limitations, bacteriocins may help to solve some actual food safety problems. The restriction imposed on antibiotics use in foods and feeds, and considering the effectiveness of bacteriocins, the existence of viable means through which they can be incorporated and a consumer's desire for minimally processed food, is an excellent alternative for its use in combination with other natural preservatives or agents (Deegan et al, 2006).

\section{Perspectives}

Lactic acid bacteria have been recognized as safe, and bacteriocins produced by these microorganisms may be a good solution to the problem of resurgence of resistant strains to antibiotics.

During the last decade, a large number of LABbacteriocins have been identified, and in some cases, biochemically and genetically characterized. This explosion in bacteriocin research has been favored by the recognition of the role that these producing bacteria may play in the hygienicquality assurance of food and as feed supplements (Pancheniak, 2005; Toro, 2005). However, to date only few bacteriocins are used as biopreservatives. This may be partially due to the fact that newly discovered broad-spectrum bacteriocins have yet to be fully characterized and officially approved. Further research is required to gain insight into the molecular mechanisms involved in bacteriocin production, immunity and mode of action, which is necessary for safe and effective exploitation of 
LAB-bacteriocins, either in the feed and food industry.

There is a need to attract consumer attention to the existence of natural substances that can protect against food-borne related illness. The acceptance of probiotics by the consumer was aided greatly when such bacteria were marketed as natural cultures that aid in digestion and health. In the same way, bacteriocins and bacteriocin-producing cultures should be attractive, especially as a consequence of consumer distrust of chemical preservatives.

Since bacteriocins are considered natural products, they might have a good acceptance from costumers who start to demand more natural and safe food products.

Some legal drawback must however be considered for the application of novel bacteriocins as safety factors in foods and feeds as well as a continued research, since up to date only a few have been officially approved for use in food.

\section{REFERENCES}

Abee, T. (1995), Pore-forming bacteriocins of Grampositive bacteria and selfprotection mechanisms of producer organisms. FEMS Microbiol. Lett., 129, 110.

Aslim, P.; Yuksekdag, Z. N.; Sarikaya, E. and Beyatli, Y. (2005), Determination of the bacteriocin-like substances produced by some lactic acid bacteria isolated from Turkish dairy products. $L W T-$ Food Sci. Technol., 38, 691-694.

Barefoot, S. F. and Klaenhammer, T. R. (1984), Purification and characterization of the Lactobacillus acidophilus bacteriocin lactacin B. Antimicrob. Agents Chemother., 26, 328-334.

Belkum, M. J.; Hayema, B. J.; Geis, A.; Kok, J. and Venema, G. (1989), Cloning of two bacteriocin genes from a lactococcal bacteriocin plasmid. Appl. Environ. Microbiol., 55, 1187-1191.Bhunia, A. K.; Johnson, M. C. and Ray, B. (1987), Direct detection of an antimicrobial peptide of Pediococcus acidilactici in sodium dodecyl sulfatepolyacrylamide gel-electrophoresis. J. Ind. Microbiol., 2, 319-322.

Bouttefroy, A. and Milliere, J. (2000), Nisin-curvaticin 13 combinations for avoiding the regrowth of bacteriocin resistant cells of bacteriocin resistant cells of Listeria monocytogenes ATCC 15313. Int. J. Food Microbiol., 62, 65-75.

Broadbent, J. R.; Chou, C.; Guillies, K. and Kondo, J. K. (1989), Nisin inhibits several gram-positive, mastitis-causing pathogens. J. Dairy Sci., 72, 33423345 .
Bruno, M. E. C. and Montville, T. J. (1993), Common mechanistic action of bacteriocins from lactic-acid bacteria. Appl. Environ. Microbiol., 59, 3003-3010.

Buchman, G.; Banerjee, S. and Hansen, J. (1998), Structure, expression and evolution of gene encoding the precursor of nisin, a small protein antibiotic. $J$. Biol. Chem., 263, 16260-16266.

Burlanek, L. L. and Yousef, A. E. (2000), Solvent extraction of bacteriocins from liquid cultures. $L$. Appl. Microbiol., 31, 193-197.

Caplice, E. and Fitzgerald, G. F.. (1999), Food fermentation: role of microorganisms in food production and preservation. Int. J. Food Microbiol., 50, 131-149.

Caridi, A. (2002), Selection of Escherichia coliinhibiting strains of Lactobacillus paracasei subsp. paracasei. J. Ind. Microbiol. Biotechnol., 29, 303308.

Carr, F.J.; Hill, D. and Maida, N. (2002), The lactic acid bacteria: A literature survey. Crit. Rev. Microbiol., 28, 281-370.

Castellano, P.; Farías, M. E.; Holzapfel, W. and Vignolo, G. (2001), Sensitivity variations of Listeria strains to the bacteriocins, lactocin 705 , enterocin CRL35 and nisin. Biotechnol. Lett., 23, 605-608.

Castellano, P.; Raya, R. and Vignolo, G. (2003), Mode of action of lactocin 705, a two-component bacteriocin from Lactobacillus casei CRL705. Int. J. Food Microbiol., 85, 35-43.

Castellano, P. and Vignolo, G. (2006), Inhibition of Listeria innocua and Brochothrix thermosphacta in vacuum-packaged meat by addition of bacteriocinogenic Lactobacillus curvatus CRL705 and its bacteriocins. Lett. Appl. Microbiol., 43, 194199.

Cheigh, C.; Kook, M.; Kim, S.; Hong, Y. and Pyun, Y. (2004), Simple one-step purification of nisin Z from unclarified culture broth of Lactococcus lactis subsp. lactis A164 using expanded bed ion exchange chromatography. Biotechnol. Lett., 26, 1341-1345.

Chopra, I.; Hodgson, J.; Metcalf, B. and Poste, G. (1998), The search for antimicrobial agents effective against bacteria resistant to multiple antibiotics. Antimicrob. Agents Chemoter., 41, 497-503.

Chumchalova, J. Stiles, J.; Josephsen, J. and Plocková, M. (2004), Characterization and purification of acidocin $\mathrm{CH} 5$, a bacteriocin produced by Lactobacillus acidophilus CH5. J. Appl. Microbiol., 96, 1082-1089.

Chung, K.; Dickson, J. and Creouse, J. (1989), Effects of nisin on growth of bacteria attached to meat. Appl. Environ. Microbiol., 55, 1329-1333.

Cintas, L. M.; Herranz, C.; Hernández, P. E.; Casaus, M. P. and Nes, L. F. (2001), Review: Bacteriocins of lactic acid bacteria. Food Sci. Tech. Int., 7, 281-305. 
Contreras, B. G. L.; De Vuyst, L.; Devreese, B.; Busanyova, K.; Raymaeckers, J.; Bosman, F.; Sablon, E. and Vandamme, E. J. (1997), Isolation, purification, and amino acid sequence of lactobin $\mathrm{A}$, one of the two bacteriocins produced by Lactobacillus amylovorus LMG P-13139. Appl. Environ. Microbiol., 63, 13-20.

Coughlin, R. T. and Crabb, J. H. (2002), Method of purifying lantibiotics. United States Patent 6794181.

Coventry, M. J.; Gordon, J. B.; Alexander, M.; Hickey, M. W. and Wan, J. (1996), A food-grade process for isolation and partial purification of bacteriocins of lactic acid bacteria that uses diatomite calcium silicate. Appl. Environ. Microbiol., 62, 17641769.

Cuozzo, S. A.; Castellano, P.; Sesma, F. J. M.; Vignolo, G. M. and Raya, R. R. (2001), Differential roles of the two-component peptides of lactocin 705 in antimicrobial activity. Current Microbiol., 46, 180183.

Cuozzo, S. A.; Sesma, F.; Palacios, J. M.; De Ruiz Holgado, A. P. and Raya, R. R. (2000), Identification and nucleotide sequence of genes involved in the synthesis of lactocin 705, a two-peptide bacteriocin from Lactobacillus casei CRL 705. FEMS Microbiol. Lett., 185, 157-161.

Daba, H.; Pandian, S.; Gosselin, J. F.; Simard, R. E.; Huang, J. and Lacroix, C. (1991), Detection and activity of bacteriocin produced by Leuconostoc mesenteroides. Appl. Environ. Microbiol., 57, 34503455.

Deegan, L. H.; Cotter, P. D.; Hill, C. and Ross, P. (2006), Bacteriocins: Biological tools for biopreservation and shelf-life extension. Int. Dairy J., 16, 1058-1071.

Dellaglio, F.; De Roissart, H.; Curk, M. C. and Janssens, D. (1994), Caractéristiques générales des bactéries latiques. In-Bactéries Latiques, H. De Roissart and F. M. Luquet, Lorica.

De Martinis, E. C. P. ; Públio, M. R. P.; Santarosa, P. R. and Freitas, F. Z. (2001), Antilisterial activity of lactic acid bacteria isolated from vacuum-packaged Brazilian meat and meat products. Braz. J. Microbiol., 32, 32-37.

De Martinis, E. C. P.; Alves, V. F. and Franco, B. D. G. De M. (2002), Bioconservação de alimentos. Biotecnologia, Ciência and Desenvolvimento, 29, 114-119.

De Martinis, E. C. P., Satarosa, P. R. and Freitas, F. Z. (2003), Preliminary characterization of bacteriocins produced by six lactic acid bacteria strains isolated from vacuum-packaged meat products. Ciênc. Tecnol. Aliment., 23, 195-199, 2003.

De Vuyst, L. and Vandamme, E. J. (1992), Influence of the carbon source on nisin production in Lactococcus lactis subsp. Lactis batch fermentations. J. Gen. Microbiol., 138, 571-578.
De Vuyst L. (1994), Nisin production variability between natural Lactococcus lactis subsp. lactis strains. Biotechnol. Lett., 16, 287-292.

De Vuyst, L. (1995), Nutritional factors affecting nisin production by Lactococcus lactis subsp. lactis NIZO 22186 in a synthetic medium. J. Appl. Bacteriol., 78, $28-33$.

Deraz, S. F.; Karlsson, E. N.; Hedstrom, M.; Andersson, M. M. and Mattiasson, B. (2005), Purification and characterisation of acidocin D20079, a bacteriocin produced by Lactobacillus acidophilus DSM 20079. J. Biotechnol., 117, 343-354.

Eijsink, V. G. H.; Skeie, M.; Middelhoven, P. H.; Brurberg, M. B. and Nes, I. F. (1998), Comparative studies of class IIa bacteriocins of lactic acid bacteria. Appl. Environ. Microbiol., 64, 3275-3281.

Engelke, G.; Gutowski-Eckel, Z; Hammelman, M, and Entian, K. D. (1992), Biosynthesis of the lantibiotic nisin: genomic organization and membrane localization of the nisb protein. Appl. Environ. Microbiol., 58, 3730-3743.

Engelke, G.; Gutowskieckel, Z.; Kiesau, P.; Siegers, K.; Hammelman, M. and Eltian, K. D. (1994), Regulation of nisin byosinthesis and immunity in Lactococcus lactis 6F3. Appl. Environ. Microbiol., 60, 814-825.

Ennahar, S.; Sashihara, T.; Sonomoto, K. and Ishizaki, A. (2000), Class Iia bacteriocins: biosynthesis, structure and activity. FEMS Microbiol. Rev., 24, 85106.

Fisher, J. F.; Meroueh, S. O. and Mobashery, S. (2005), Bacterial resistance to beta-lactam antibiotics: compelling opportunism, compelling opportunity. Chem. Rev., 105, 395-424.

Fuller, R. (1989), Probiotics in man and animals. $J$. Appl. Bacteriol., 66, 365-378.

Galvin, M.; Hill, C. and Ross, R. P. (1999), Lacticin 3147 displays activity in buffer against Gram-positive pathogens which appear insensitive in standard plate assays. Lett. Appl. Microbiol., 28, 355-358.

Garrity, G. M. (1984), Bergey's manual of sistematic bacteriology, vol. 2: the proteobacteria, Williams and Wilkins, New York.

Geisen, R.; Becker, B. and Holzapfel, W. H. (1993), Bacteriocin production of Leuconostoc carnosum LA54A at different combinations of $\mathrm{pH}$ and temperature. J. ind. Microbiol., 12, 337-340.

González-Martínez, B. E.; Gómez-Treviño, M. and Jiménez-Salas, Z. (2003), Bacteriocinas de probióticos. Rev. Salud Pública y Nutrición, 4.

Gross, E. and Morell, J. L. (1971), Structure of nisin. J. Am. Chem. Soc., 93, 4634-4635.

Guder, A.; Wiedemann, I. and Sahl, H. G. (2000), Posttranslationally modified bacteriocins: the lantibiotics. Biopoolymers, 55, 62-73.

Guinane, C.M.; Cotter, P. D.; Hill, C. and Ross, R. P. (2005), Microbial solutions to microbial problems; lactococcal bacteriocins for the control of undesirable biota in food. J. Appl. Microbiol., 8, 1316-1323. 
Guinane, C. M.; Cotter, P. D.; Hill, C. and Ross, R. P. (2006), Spontaneous resistance in Lactococcus lactis IL1403 to the lantibiotic lacticin 3147. FEMS Microbiol. Lett., 260, 77-83.

Guyonnet, D.; Fremaux, C.; Cenatiempo, Y. and Berjeaud, J. M. (2000), Method for rapid purification of class IIa bacteriocins and comparison of their activities. Appl. Environ. Microbiol., 66, 1744-1748.

Haller, D.; Colbus, H.; Gänzle, M. G.; Scherenbacher, P.; Bode, C. and Hammes, W. P. (2001), Metabolic and functional properties of lactic acid bacteria in the gastro-intestinal ecosystem: a comparative in vitro study between bacteria of intestinal and fermented food origin. System. Appl. Microbiol., 24, 218-226.

Hastings, J. W.; Sailer, M.; Johnson, K.; Roy, K. L.; Vederas, J. C. and Stiles, M. E. (1991), Characterization of leucocin A-UAL 187 and cloning of the bacteriocin gene from Leuconostoc gelidum. J. Bacteriol., 173, 7491-7500.

Hernández, D.; Cardell, E. and Zárate, V. (2005), Antimicrobial activity of lactic acid bacteria isolated from Tenerife cheese: initial characterization of plantaricin TF711, a bacteriocin-like substance produced by Lactobacillus plantarum TF711. J. Appl. Microbiol., 99, 77-84.

Ivanova, I.; Miteva, V.; Stefanova, T. S.; Pantev, A.; Budakov, I.; Danova, S.; Moncheva, P.; Nikolova, I.; Dousset, X. and Boyaval, P. (1998), Characterization of a bacteriocin produced by Streptococcus thermophilus 81. Int. J. Food microbiol., 42, 147158.

Jack, R. W.; Tagg, J. R. and Ray, B. (1995), Bacteriocins of Gram-positive bacteria. Microbiol. Rev., 59, 171-200.

Joerger, M. C. and Klaenhammer, T. R. (1986), Characterization and purification of helveticin $\mathrm{J}$ and evidence for a choromosomally determined bacteriocin produced by Lactobacillus helveticus 481 . J. Bacteriol., 167, 439-446.

Kaletta, C. and Entian, K. D. (1989), Nisin, a peptide antibiotic: cloning and sequencing of the nis $A$ gene and posttraductional processing of its peptide product. J. Bacteriol., 171, 1597-1601.

Kapil, A. (2005), The challenge of antibiotic resistance: need to contemplate. Indian J. Med. Res. 121, 83-91.

Kim, W. S.; Hall, R. J. and Dunn, N. W. (1997), The effect of nisin concentration and nutrient depletion on nisin production of Lactococcus lactis. Appl. Microbiol. Biotechnol., 48, 449-453.

Kim, W. S.; Hall, R. J. and Dunn, N. W. (1998), Improving nisin production by increasing nisin immunity/resistance genes in the producer organism Lactococcus lactis. Appl. Microbiol Biotechnol., 50, 429-433.

Klaenhammer, T. R.; Fremaux, C. and Hechard, Y. (1994), activité antimicrobienne des bactéries lactiques. In-Bactéries Latiques, H. De Roissart and F. M. Luquet, Lorica.
Koponen, O. (2004), Studies of producer self-protection and nisin biosynthesis of Lactococcus lactis. $\mathrm{PhD}$ Thesis, University of Helsinki, Helsinki, Finland.

Kuipers, O. P.; Beerthuyzen, M. M.; Siezen, R. J. and Devos, W. M. (1993), Characterization of the nisin gene-cluster nisABTCIPR of Lactococcus lactisrequirement of expression of the nisA and nisI genes for development of immunity. Eur. J. Biochem., 216, 281-291.

Kumar, A. and Schweiser, H. P. (2005), Bacterial resistance to antibiotics: active efflux and reduced uptake. Adv. Drug Deliv. Rev., 57, 1486-1513.

Lade, H. S.; Chitanand, M. P.; Gyananath, G. and Kadam, T. A. (2006), Studies on some properties of bacteriocins produced by Lactobacillus species isolated from agro-based waste. The Internet $J$. Microbiol., 2(1).

Lipsitch, M.; Bergstrom, C. T. and Levin, B. R. (2000), The epidemiology of antibiotic resistance in hospitals: paradoxes and prescriptions. Proc. Natl. Acad. Sci. USA, 97, 1938-1943.

Liserre, A. M.; Landgraf, M.; Destro, M. T. and Franco, B. D. G. M. (2002), Inhibition of Listeria monocytogenes by a bacteriocinogenic Lactobacillus sake strain in modified atmosphere-packaged Brazilian sausage. Meat Sci., 61, 449-455.

Lv, W.; Zhang, X. and Cong, W. (2005), Modelling the production of nisin by Lactococcus lactis in fed-batch culture. Appl. Microbiol. Biotechnol., 68, 322-326.

Mackay, V. C.; Arenose, G. and Hastings, J. W. (1997), Purification of bacteriocins of lactic acid bacteria: problems and pointers. J. Food Microbiol., 34, 1-16.

Martinez, R. C. R. and De Martinis, E. C. P. (2005), Antilisterial activity of a crude preparation of Lactobacillus sakei 1 bacteriocin and its lack of influence on Listeria monocytogenes haemolytic activity. Food Control, 16, 429-433.

Martinez, R. C. R. and De Martinis, E. C. P. (2005), Evaluation of bacteriocin-producing Lactobacillus sakei 1 against Listeria monocytogenes 1/2a growth and haemolytic activity. Braz. J. Microbiol., 36, 8387.

Martinez, R. C. R. and De Martinis, E. C. P. (2006), Effect of Leuconosoc mesenteroides 11 bacteriocin in the multiplication control of Listeria monocytogenes. Ciênc. Tecnol. Aliment., 26, 52-55.

McAuliffe, O.; Ryan, M. P.; Ross, R. P.; Hill, C.; Breeuwer, P. and Abee, T. (1998), Lacticin 3147, a broad-spectrum bacteriocin which selectively dissipates the membrane potential. Appl. Environ. Microbiol., 64, 439-445.

Messi, P.; Bondi, M; Sabia, C.; Battini, R. and Manicardi, G. (2001), Detection and preliminary characterization of a bacteriocin (plantaricin 35d) produced by a Lactobacillus plantarum strain. Int. J. Food Microbiol., 64, 193-8. 
Minahk, C. J.; Farias, M. E.; Sesma, F. and Morero, R. D. (2000), Effect of enterocin CRL35 on Listeria monocytogenes cell membrane. FEMS Microbiol. Lett., 192, 79-83.

Moreno, I.; Lerayer, A. S. L. and Leitão, M. F. F. (1999), Detection and characterization of bacteriocinproducing Lactococcus lactis strains. Rev. Microbiol. 30, 130-136.

Moreno, I.; Lerayer, A S. L.; Baldini, V. L. S. and Leitão, M. F. de F. (2000), Characterization of bacteriocins produced by Lactococcus lactis strains. Braz. J. Microbiol., 31, 184-192.

Morisset, D.; Berjeaud, J. M.; Marion, D.; Lacombe, C. and Frère, J. (2004), Mutational analysis of mesentericin Y105, an anti-Listeria bacteriocin, for determination of impact on bactericidal activity, in vitro secondary structure, and membrane interaction. Appl. Environ. Microbiol., 70, 4672-4680.

Muriana, P. M. and Klaenhammer, T.R. (1991), Purification and partial characterization of lactacin F, a bacteriocin produced by Lactobacillus acidophilus 11088. Appl. Environ. Microbiol., 57, 114-121.

Mørtvedt, C. I.; Nissen-Meyer, J.; Sletten, K. and Nes, I. F. (1991), Purification and amino acid sequence of lactocin $\mathrm{S}$, a bacteriocin produced by Lactobacillus sake L45. Appl. Environ. Microbiol., 57, 1829-1834.

Ohmomo, S.; Murata, S.; Katayaman, N.; Nitisinprasart, S.; Kobayashi, M.; Nakajima, T.; Yajima, M. and Nakanishi, K. (2000), Purification and some characteristics of enterocin ON-157, a bacteriocin produced by Enterococcus faecium NIAI 157. J. Appl. Microbiol., 88, 81-89.

Osmanagaoglu, Ö.; Gündüz, U.; Beyatli, Y. and Çökmüs, C. (1998), Purification and characterization of pediocin F, a bacteriocin produced by Pediococcus acidilactici F. Tr. J. Biol., 22, 217-228.

Pancheniak, E. de F. R. (2005), Isolamento, seleção, caracterização bioquímica e molecular, otimização de bioprocesso para produção e avaliação do potencial probiótico de Lactobacillus reuteri LPB no desempenho de leitões desmamados. PhD Thesis, Universidade Federal do Paraná, Curitiba, Brazil.

Pancheniak, E. de F. R.; Parada, J. L. and Soccol, C. R. (2006), Inibição de Escherichia coli hemolítica suina por Lactobacillus reuteri, produtor de reuterina. Paper presented at XX Congresso Brasileiro de Ciência e Tecnologia de Alimentos, 8-11 Oct, Curitiba, Paraná.

Parada, J. L.; Gaón, D. and Chekherdemian, M. (1980), Enfoque bioquímico y genético de la resistencia a los antibióticos. Ars Curandi, 4, 240-245.

Parada, J. L. (1984), Bacterias Lácticas y el mejoramiento de microorganismos de uso industrial. La Alimentación Latinoamericana, 146, 93-102.

Parada J. L. (1985), Genética microbiana para o melhoramento de bacterias lácticas utilizadas na industria láctea. In-Genética de Microorganismos en Biotecnología e Engenharia Genética. Ed. J. L. Acevedo. FEALQ. Brasil.
Parada, J. L. (2000), Probióticos y Prebióticos. Reseña Farm Bioquim,. 3, 3-7.

Parada, J. L.; Sambucetti, M. E.; Zuleta, A. and Rio, M. E. (2003), Lactic acid fermented products as vehicles for probiotics.In-New Horizons in Biotechnology. Kluwer Academc Publishers, Boston, Londres, pp. 335-351.

Piva, A. and Headon, D. R. (1994), Pediocin A, a bacteriocin produced by Pediococcus pentosaceus FBB61. Microbiol., 140, 697-702.

Quiao, M.; Omaetxebarria, M. J.; Ra, R.; Oruetxebarria, I. and Saris, P. E. J. (1997), Isolation of a Lactococcus lactis strain with high resistance to nisin and increased nisin production. Biotech. Lett., 19, 199-202.

Rao, G. G. (1998), Risk factors for the spread of antibiotic-resistant bacteria. Aids Int., 55, 323-330.

Rasch, M. and Knochel, S. (1998), Variations in tolerance of Listeria monocytogenes to nisin, pediocin PA-! and bavaricin A. Lett. Appl. Microbiol., 27, 275-278.

Rekhif, N.; Atrih, A. and Lefebvre, G. (1994), Selection and properties of spontaneous mutants of Listeria monocytogenes ATCC 15313 resistant to different bacteriocins produced by lactic acid bacteria strains. Current Microbiol., 28, 237-241.

Rodríguez, E.; Arqués, J. L.; Rodríguez, R.; Nuñez, M. and Medina, M. (2003), Reuterin production by lactobacilli isolated from pig faeces and evaluation of probiotic traits. Lett. Appl. Microbiol., 37, 259-263.

Rodriguez, J. M. (1996), Review: Antimicrobial spectrum, structure, properties and mode of action of nisin, a bacteriocin produced by Lactococcus lactis. Food Sci. Technol. Int., 2, 61-68.

Ross, P. R.; Galvin, M.; McAuliffe, O.; Morgan, S. M.; Ryan, M. P.; Twomey, D. P.; Meaney, W. J. and Hill, C. (1999), Developing applications for lactococcal bacteriocins. Antonie van Leeuwenhoek, 76, 337-346.

Roy, P. H. (1997), Dissemination of antibiotic resistance. Med.Sci., 13, 927-933.

Ryan, M. P.; Meaney, W. J.; Ross, R. P. and Hill, C. (1998), Evaluation of lacticin 3147 and a teat seal containing this bacteriocin for inhibition of mastitis pathogens. Appl. Environ. Microbiol., 64, 2287-2290.

Saavedra, L.; Minahk, C.; Holgado, A. P. De R. and Sesma, F. (2004), Enhancement of the enterocin CRL35 activity by a synthetic peptide derived from the NH2-terminal sequence. Antimicrob. Agents Chemother., 48, 2778-2781.

Sahl, H. G. and Bierbaum, G. (1998), LANTIBIOTICS: Biosynthesis and biological activities of uniquely modified peptides from Gram-positive bacteria. Annu. Rev. Microbiol., 52, 41-79.

Schöbitz, R.; Zaror, T.; León, O. and Costa, M. (1999), A bacteriocin from Carnobacterium piscicola for the control of Listeria monocytogenes in vacuumpackaged meat. Food Microbiol., 16, 249-255. 
Schöbitz, R.; Suazo, V.; Costa, M. and Ciampi, L. (2003), Effects of a bacteriocin-like inhibitory substance from Carnobacterium piscicola against human and salmon isolates of Listeria monocytogenes. Int. J. Food Microbiol., 84, 237-244.

Schöbitz, R. P.; Bórquez, P. A.; Costa, M. E.; Ciampi, L. R. and Brito, C. S. (2006), Bacteriocin like substance production by Carnobacterium piscicola in a continuous system with three culture brooths. study of antagonism against Listeria monocytogees in vacuum packaged salmon. Braz. J. Microbiol., 37, 52-57.

Schillinger, U.; Becker, B.; Vignolo, G. and Holzapfel, W. H. (2001), Efficacy of nisin in combination with protective cultures against Listeria monocytogenes Scott A in tofu. Int. J. Food Microbiol., 71, 159-168.

Sobrino, O. J.; Rodriguez, J. M.; Moreira, W. L.; Cintas, L. M.; Fernandez, M. F.; Sanz, B. and Hernandez, P. E. (1992), Sakacin M, a bacteriocinlike substance from Lactobacillus sake 148. Int. J. Food Microiol., 16, 215-25.

Stevens, K. A.; Sheldon, B. W.; Klapes, N. A. and Klaenhammer, T. R. (1991), Nisin treatment for inactivation of Salmonella species and other Gramnegative bacteria. Appl. Environ. Microbiol., 57, 3613-3615.

Suarez, A. M.; Azcona, J. I.; Rodríguez, J. M.; Sanz, B. and Hernández P. E. (1997), One-step purification of nisin A by immunoaffinity chromatography. Appl. Environ. Microbiol., 63, 4990-4992.

Toro, C. R. (2005), Uso de bactérias láticas probióticas na alimentação de camarões Litopenaeus vannamei como inibidoras de microrganismos patogênicos e estimulantes do sistema imune. PhD Theses, Universidade Federal do Paraná, Curitiba, Brazil.

Torodov, S. D. and Dicks, L. M. T. (2004), Effect of medium components on bacteriocin production by Lactobacillus pentosus ST151BR, a strain isolated from beer produced by the fermentation of maize, barley and soy flour. World J. Micobiol. Biotechnol., 20, 643-650.

Torodov, S. D. and Dicks, L. M. T. (2005), Lactobacillus plantarum isolated from molasses produces bacteriocins active against Gram-negative bacteria. Enzyme and Microbial. Technol., 36, 318326.

Vandermeer, J. R.; Polman, J.; Beerthuyzen, M. M.; Siezen, R. J.; Kuipers, O. P. and Devos, W. M. (1993), Characterization of the Lactococcus-lactis nisin-a operon genes nisP, encoding a subtilisin-like serine protease involved in precursor processing, and $n i s R$, encoding a regulatory protein involved in nisin biosynthesis. J. Bacteriol., 175, 2578-2588.

Vaughan, E. E.; Daly, C. and Fitzgerald, G. F. (1992), Identification and characterization of helveticin V1829, a bacteriocin produced by Lactobacillus helveticus 1829. J. Appl. Bacteriol., 73, 299-308.
Venema, K.; Chikindas, M. L.; Seegers, J. F. M. I.; Haandrikman, A. J.; Leenhouts, K. J.; Venema, G. and Kok, J. (1997), Rapid and efficient purification method for small, hydrophobic, cationic Bacteriocins: purification of lactococcin B and pediocin PA-1. Appl. Environ. Microbiol., 63, 305-309.

Vignolo, G.; Fadda, S.; De Kairuz, M. N.; De Ruiz Holgado, A. A. and Oliver, G. (1996), Control of Listeria monocytogenes in ground beef by lactocin 705, a bacteriocin produced by Lactobacillus casei CRL 705. Food Microbiol., 29, 397-402.

Vignolo, G.; Fadda, S.; Dekairuz, M. N.; Holgado, A. P. D. and Oliver, G. (1998), Effects of curing additives on the control of Listeria monocytogenes by lactocin 705 in meat slurry. Food Microbiol., 15, 259-264.

Vignolo, G.; Palacios, J.; Farías, M. E.; Sesma, F.; Schillinger, U.; Holzapfel, W. and Olliver, G. (2000), Combined effect of bacteriocins on the survival of various Listeria species in broth and meat system. Current Microbiol., 41, 410-416.

Xiraphi, N.; Georgalaki, M.; Van-Driessche, G.; Devreese, B.; Van-Beeumen, J.; Tsakalidou, E.; Metaxopoulos, J. and Drosinos, E. H. (2006), Purification and characterization of curvaticin L442, a bacteriocin produced by Lactobacillus curvatus L442. Antonie Van Leeuwenhoek, 89, 19-26.

Yang, R.; Johnson, M. C. and Ray, B. (1992), Novel method to extract large amounts of bacteriocins from lactic acid bacteria. Appl. Environ. Microbiol., 58, 3355-3359.

Yang, R. and Ray, B. (1994), Factors influencing production of bacteriocins by lactic acid bacteria. Food Microbiol., 11, 281-291.

Yoneyama, H. and Katsumata, R. (2006), Antibiotic Resistance in Bacteria and Its Future for Novel Antibiotic Development. Biosci. Biotechnol. Biochem., 70, 1060-1075.
Received: June 06, 2005; Revised: February 08, 2006; Accepted: March 09, 2007. 